\title{
Population Dynamics and Feeding Potentiality of a New Species Cunexa terminalae sp. Nov. Collected from Sundarban Biosphere Reserve
}

\author{
Sanjib Ghoshal* \\ Department of Zoology, Bangabasi College, Kol-700009, India \\ *Corresponding author
}

\begin{tabular}{|c|c|}
\hline & A B S T R A C T \\
\hline $\begin{array}{l}\text { Ke y w o r d s } \\
\text { New species, } \\
\text { Sundarbans, } \\
\text { Population } \\
\text { Dynamics. }\end{array}$ & \multirow{3}{*}{$\begin{array}{l}\text { During the meticulous survey in the different regions of Sundarbans } \\
\text { Biosphere Reserve the author is discovered a new species of mite and } \\
\text { describe its chetotaxy and biometry in an international journal. The species } \\
\text { is new to the world. Since no works regarding the population dynamics of } \\
\text { this newly described species is done so far, it is given in this present study. } \\
\text { The species was reported by the author from Sajnekhali Tiger Reserve, } \\
\text { within Sundarban Biosphere Reserve, 24-Paraganas (south). The species } \\
\text { was collected from Arjun tree. It was found that the highest population of } \\
\text { this mite was shown during March-April, } 2016 \text { and minimum population } \\
\text { was during July-August, } 2016 \text {. }\end{array}$} \\
\hline Article Info & \\
\hline $\begin{array}{l}\text { Accepted: } \\
\text { 04 July } 2017 \\
\text { Available Online: } \\
\text { 10 September } 2017\end{array}$ & \\
\hline
\end{tabular}

\section{Introduction}

Previous studies reported that a good number of plant mites are injurious pests of agricultural and horticultural crops causing considerable yield loss (Gupta, 2003). During the meticulous survey in the different regions of Sundarbans Biosphere Reserve the author is discovered a new species of mite and describe its chaetotaxy and biometry in an international journal. The species is new to the world. Since it is a newly described predatory species reported from Arjun tree in Sundarbans Biosphere Reserve and no study was made on the population fluctuation of this predatory mite on these plants, it was thought desirable to conduct a study on the population dynamics of this mite. It will provide information about the time of abundance of this species. This will help farmers in biological control of this mite.

\section{Materials and Methods}

Collection is made directly from the infested leaves by examining those under a $20 \mathrm{X}$ magnification glass in the field. The mites were collected with fine sable hairbrush moistened with $70 \%$ ethanol.

Collected samples were kept in small glass vials $(3 \times 1 \mathrm{~cm})$ in $70 \%$ ethanol. Specimens were collected under a dissecting microscope with a fine brush and were put in a drop of lactic acid on a glass slide and then they were covered with a broken piece of cover glass to 
minimize the weight of the glass on the specimens.

Ten Arjun trees of almost the same age were sampled and all those were tagged. From each tree, ten leaves of the same size and age were randomly collected. An area of $6.25 \mathrm{~cm}^{2}$ on the ventral surface of each leaf was examined for mites using a $20 \mathrm{x}$ hand lens. Sampling was repeated at a three-week interval.

The relevant meteorological data on temperature, relative humidity and rainfall were collected for the entire study period by a digital device (Digital thermo-hygrometer by Citizen biotech). The data were subjected to a Pearson correlation analysis to determine the degree of association between simple correlation coefficients. (Statistical Package used: SPSS, ver-12)

\section{Results and Discussion}

In Terminalia arjuna the mite population size was average i.e., $12.3 \pm 0.45$ mites $/ 6.25 \mathrm{~cm}^{2}$ to $11.4 \pm 0.28$ mites $/ 6.25 \mathrm{~cm}^{2}$ during
November, 2015 - January, 2016. A population size peak was observed during March, 2016 (33.4 \pm 0.56 mites / $6.25 \mathrm{~cm}^{2}$, mean $\pm \mathrm{SD}$ is calculated) when mean temperature, $\mathrm{RH}$ and rainfall were $28.56 \pm$ $2.07{ }^{0} \mathrm{C}, 62.33 \pm 4.87 \%$ and $0.033 \pm 0.01 \mathrm{~mm}$ (mean \pm SD is calculated) respectively.

The population declined thereafter reaching the minimum in August, 2016 (5.45 \pm 0.91 mites $/ 6.25 \mathrm{~cm}^{2}$ ) when the mean temperature, $\mathrm{RH}$ and rainfall were $28.91 \pm 2.22^{\circ} \mathrm{C}, 84.50 \pm$ $3.42 \%$, and $15.53 \pm 6.21 \mathrm{~mm}$ respectively (Table 1).

Increased precipitation in June and July, 2016, probably acted adversely on the mite population. From September 2016 onwards the population again started to increase.

The correlation coefficient of the mite density with temperature was positive while, with relative humidity and rainfall it was found to be negative. Correlation with rainfall was found to be significant but it was nonsignificant in the other two cases.

Table.1 Population size of Hypoaspis xylocarpi on Xylocarpus granatum per $6.25 \mathrm{~cm}^{2}$ leaf area recorded form Nov. 2015 to Oct. 2016. (Data are given as mean \pm SD)

\begin{tabular}{|c|c|c|c|c|}
\hline Months & Mites $(\mathrm{n}=100)$ & Average temp $\left({ }^{\circ} \mathrm{c}\right)$ & Average Humidity $(\%)$ & Average rainfall $(\mathrm{mm})$ \\
\hline Nov 2015 & $12.3 \pm 0.45$ & $25.41 \pm 2.10$ & $75.00 \pm 5.12$ & $0.71 \pm 0.08$ \\
\hline Dec 2015 & $11.5 \pm 0.63$ & $21.10 \pm 1.33$ & $69.51 \pm 6.35$ & $0 \pm 0.0$ \\
\hline Jan 2016 & $11.4 \pm 0.28$ & $20.32 \pm 2.33$ & $72.97 \pm 8.29$ & $0.64 \pm 0.22$ \\
\hline Feb 2016 & $17.6 \pm 0.79$ & $23.50 \pm 2.00$ & $65.99 \pm 5.36$ & $0 \pm 0.0$ \\
\hline Mar 2016 & $\mathbf{3 3 . 4} \pm \mathbf{0 . 5 6}$ & $28.56 \pm 2.07$ & $62.33 \pm 4.87$ & $0.033 \pm 0.01$ \\
\hline Apr 2016 & $\mathbf{3 1 . 1} \pm \mathbf{0 . 0 9}$ & $29.5 \pm 2.66$ & $67.58 \pm 3.99$ & $2.54 \pm 0.93$ \\
\hline May2016 & $30.6 \pm 0.76$ & $31.28 \pm 1.21$ & $72.62 \pm 4.56$ & $1.05 \pm 0.87$ \\
\hline Jun 2016 & $30.5 \pm 0.23$ & $29.00 \pm 1.34$ & $83.50 \pm 4.77$ & $0.15 \pm 0.22$ \\
\hline July2016 & $\mathbf{9 . 6 0 \pm 0 . 5 6}$ & $30.6 \pm 2.37$ & $78.29 \pm 7.01$ & $12.92 \pm 3.45$ \\
\hline Aug 2016 & $\mathbf{5 . 4 5} \pm \mathbf{0 . 9 1}$ & $28.91 \pm 2.22$ & $84.5 \pm 3.42$ & $15.53 \pm 6.21$ \\
\hline Sep2016 & $7.6 \pm 0.45$ & $27.10 \pm 2.11$ & $82.76 \pm 3.22$ & $10.49 \pm 4.87$ \\
\hline Oct2016 & $10.9 \pm 0.98$ & $27.69 \pm 2.14$ & $72.79 \pm 5.01$ & $2.28 \pm 1.11$ \\
\hline
\end{tabular}

Table.2 Correlation between the mite density and three environmental variables

\begin{tabular}{|c|c|c|c|}
\hline & Temperature & Relative humidity & Rainfall \\
\hline Mite population & 0.326 & -0.301 & $-0.598^{*}$ \\
\hline
\end{tabular}

\footnotetext{
* = significant, according to the J.P. Guilford's product moment coefficient of correlation table.
} 
Several general studies on seasonal occurrence of phytophagous mites are available. For raoiella indica Hirst on coconut, population density was positively correlated with temperature and negatively correlated with $\mathrm{RH}$ and rainfall (Nageschandra and Channabasavanna, 1984), which is contrary to the present findings where it was positively correlated with temperature, $\mathrm{RH}$ and negatively correlated with rainfall. Gupta et al., (1976) reported negative correlation with temperature and positive correlation with $\mathrm{RH}$ and rainfall for Tetranychus telarius on castor. Nageschandra and Channabasavanna (1984) reported a peak of population density of Raoiella indica in February on guava and in other months for other crops. Contrary to this, Dhooria and Butani (1983) reported peak population of Eutetranychus orientalis on citrus during May-June as well as in September while Lal (1982) reported peak population during January-April. The present study shows similarities with the studies made by Ghoshal et al., (2004). According to him, hot dry wind favored its population growth and the same was also reported by Dean (1959), Lal and Mukherji (1979), Puttaswamy and Channabasavanna (1981), Lal (1982), and Sugeetha and Shrinivasa (1999). Dhooria and Gupta (1975) and Kumari and Sadana (1995) reported peak population of Brevipalpus phoenicis on guava during November December. Therefore, the present report does not totally agree with published data.

The present results showed a peak in population density in may, 2016 which is similar to results of Dhooria and Butani (1983). These authors show two peaks in May-June as well in September. Our results, however, disagree with those of Dhooria and Gupta (1975) who reported a peak in December. Most of the previous studies reported that mite population was reduced drastically with low temperature and rainfall
(Oatman and Mcmurtry, 1966; Dhooria and Butani, 1983). The peak population of different mites on Psidium guajava was reported during February and the minimum was reported in July (Ghoshal, Gupta and Mukherjee, 2006). They also reported that temperature, $\mathrm{RH}$ positively correlated while rainfall negatively correlated with the mite population.

\section{References}

Das, T.K., 1987. Studies on mites found in association with pineapple plantation. Ph.D Thesis. Bidhan Chandra krishi Viswavidyalaya, Kalyani (West Bengal). pp. 1-238.

Dean, H.A., 1959. Seasonal distribution of mites on Texas grapefruit. J. econ. Ent., 52: $228-232$.

Dhooria, M.S., and Butani, D.K. 1983. Seasonal incidence of Citrus mite, Eutetranychis orientalis and its predators. Indian Journal of Acrolology, 7: 57-62.

Dhooria, M.S., and Gupta, S.K. 1975. Seasonal abundance of mites and their predators on fruit trees in Punjab. Punjab Hort. J., 15 (3-4): 102-104.

Ghoshal Sanjib, Gupta. S.K. and Mukherjee. B. 2004. Seasonal abundance of phytophagous and predatory mites on mangrove vegetation and agrihorticultural crops of SBR. Acarina, 12(1): 49-56.

Golek, Z., 1975. A study of the destruction of the fruit tree red spider mite Panonychus ulmi (Koch) on apple. Zesz, Probl. Postepow. Nauk. Rola., 171: 1534.

Gupta, S.K., 2003. Mite pests of agricultural crops in India, their management and identification (In: Eds. Yadav, P.R., Chauhan, R., Putatunda, B.N., Chhillar, B.S) Mites, their identification and management, pp. 48-61. 
Gupta, S.K., Dhrooria, M.S. and Sidhu, A.S. 1976. Seasonal abundance of Tetranychus talarius (Linn.) on castor in the Punjab. Oilseeds journal, 6: 1618.

Hedge, J.E., and Hofreiter, B.T. 1962. In: Carbohydrate Chemistry 17 (Eds. Whistler R.L. and Miller, J.N). Academic Press New York.

Lal, L., and Mukherji, S.P. 1979. Seasonal history of three Phytophagous mites at Varanasi (UP). Indian. J. Acar.,4(2): 61-67.

Lal, S.S., 1982. Influence of weather factors on the population of spider mites (Acari: Tetranychidae) and Thrip (Thysanoptera) on Cassava in Kerala. Indian. J. Acar., 7 (10):5-10.

Nageshchandra, B.K., and Channa Basavannna, G. P. 1984. Studies on seasonal fluctuation of the population of Raoiella indica Hirst (Acari: Tenuipalpidae) on coconut with reference to weather parameters. Indian. J. Acarol., 8: 104-111.

Oatman, E.R., and McMurtry, J.A. 1966. Biological control of the two spotted spider mite on strawberry in southern California. Journal of Economic Entomology, 59: 433-439.
Puttaswamy, and Channa Basavanna, G.P. 1981. Influence of weather factors and predators on the population of spidermite T. ludeni (Acari: Tetranaychidae). Indian J. Acar., 5: 6979.

Puttaswamy, and Channa Basavanna, G.P. 1982. Effect of Temperature and Relative humidity on the development and oviposition of Tetranychus ludeni (Acari: Tetranychidae). Indian J. Acar., 4(1): 31-40.

Sadana, G.L., and Goyal M. 1984. Influence of morphological and biochemical characteristics of Host plants on the life cycle of Brevipalpyus obovatus Donnadieu (Acarina: Tenuipalpidae) Ind. J. Acarol., 8 (2): 49-56.

Sugeetha, G., and Srinivasa, N. 1999. Seasonal abundance of red spider mite Tetranychus macferlanei on Okra varieties in Bangalore, J. Acarol., 15: 10-14.

Van de Vrie, M., McMurtry, J.A. and Huffaker, C. B. 1972.Ecology of tetranychid mites and their natural enemies. A review III. Biology, ecology and pest status and host plant relations of Tetranychus. Hilgardia, 41: 343-432.

\section{How to cite this article:}

Sanjib Ghoshal. 2017. Population Dynamics and Feeding Potentiality of a New Species Cunexa terminalae sp. Nov. Collected from Sundarban Biosphere Reserve. Int.J.Curr.Microbiol.App.Sci. 6(9): 289-292. doi: https://doi.org/10.20546/ijcmas.2017.609.036 